\title{
Strategies of the Cultivation of Critical Thinking Ability in College English Reading Teaching
}

\author{
Xuemin Heng \\ Xiamen University Tan Kah Kee College, Xiamen, Fujian, China \\ Jasonhxm7708@163.com
}

Keywords: Critical Thinking, College English Reading, Cultivation

\begin{abstract}
As an important content and way of English learning, English reading is an important way to cultivate students' critical thinking ability in college. Developing critical English reading teaching, creating a good classroom atmosphere and educational environment, changing traditional reading concepts and forming a teaching culture of "critical thinking reading" are the basic prerequisites for cultivating critical thinking ability. This paper attempts to find out the common characteristics of critical thinking ability and college English reading ability, so as to find out whether there is a correlation between critical thinking ability and English reading ability of college students and whether their critical thinking ability has an impact on their English reading ability.
\end{abstract}

\section{Introduction}

Critical thinking is the main driving force for advancing the knowledge society. Today, in implementing innovative education, strengthening the critical thinking ability of college students has become one of the important goals of higher education and should be paid enough attention to. The focus of education is to cultivate students' creativity, and the key to the cultivation of creativity lies in the cultivation of students' critical thinking ability. Language and thinking are inseparable. Reading plays an important role in language learning and is an important way for students to obtain language information, expand vocabulary and improve language ability. Therefore, it is of great significance to cultivate students' critical thinking ability in English reading teaching to promote college English teaching reform. In recent years, critical thinking ability, as one of the important educational goals in the information age, has been advocated and emphasized in both western countries and China. This paper focuses on the connotation of critical reading and critical thinking ability, and discusses the relationship between critical reading and critical thinking ability. On this basis, it makes an in-depth study of the relationship between college English reading and critical thinking ability training, which has a certain reference function for further deepening college English teaching reform. The research will also be of practical significance and value, mainly in mobilizing the students' learning passion, enhancing their consciousness and awareness of self-cultivating their ability to think critically in learning college English reading, drawing the attention of the college English teachers' to cultivate the students' critical thinking and offering the relevant theoretical foundation and conclusion of research, and widening the research perspective of students' critical thinking and further enriching the research results of students' critical thinking in our country through the "cultivation of critical thinking "in the teaching of college English reading. So, in the process of English teaching, teachers should be proactive to cultivate students' ability of critical thinking. The college English reading should be perfectly combined with the education of critical thinking, and teachers should encourage students to read extensively, think actively, discuss in groups and analyze in the class to discuss more profound knowledge. To combine the cultivation of critical thinking with the subjects teaching together and develop the students' critical thinking by regular classroom teaching is the most common mean to train the students to think critically at college. 


\section{Critical Thinking and College English Reading}

China's college English teaching has been reformed many times under the impetus of reform and opening up and economic development, but it has not touched the essence of the problem. Taking the CET-4 and CET-6 as an example, a lot of efforts have been made to explore the test mode, which has indeed improved the students' English listening and speaking ability to a certain extent, compared with the previous mute English. However, in the actual teaching process, it is found that although the students' English listening and speaking ability has been strengthened, the reading ability of college English is obviously declining. English language learning is a process of discovering, defining and expressing problems. When it comes to college English teaching objectives, we have to talk about college English reading education and teaching in China. Our college English reading teaching strictly complies with the syllabus. This is not a big problem, but in the process of teaching practice, we cannot achieve the real college English teaching objectives. Examining the current college English reading teaching in our country, we overemphasize the accumulation of words and the strengthening of grammar knowledge in the classroom while neglecting the analysis, understanding and evaluation of reading materials. This traditional college English reading teaching only focuses on developing students' language knowledge and language skills, and lacks the cultivation of students' critical thinking, thus inhibiting students' critical thinking ability. Looking at the current situation of college English reading teaching, we have not really achieved critical reading. Our English teaching is always looking for the "right answer" and students can always predict or find the "right answer". In such English classroom teaching, students will not take the initiative to ask questions and always wait for the teacher to define their "examination scope" and never and will never allow students to take the initiative to ask questions, analyze problems and solve problems.

For a long time, Chinese students have developed the habit of sitting quietly listening to the teacher's lectures and copying notes, then reciting what they wrote on the notes according to the teacher's instructions, and doing some exercises with mechanical methods and methods, with little opportunity to rethink and question what the teacher taught. In this teacher-oriented class, students are more like a machine without the ability to operate independently, especially in college English learning. In English language learning, although listening and speaking are important, it is impossible to develop in-depth reading and problem analysis ability when the language reading ability does not improve. In the face of future study abroad or reading this professional English article, there will be problems in understanding the meaning and text of the language in the context. A good basis for English reading is to take time out to experience the essence of foreign culture and to absorb the excellent cultures of other countries with emotion and purpose. College English reading is not restricted by location or network signals. You can enjoy reading anytime and anywhere with a favorite book. You can improve your language and grammar skills gradually in the environment where you are accustomed to reading, then the listening and speaking ability will naturally improve rapidly in a certain environment. Therefore, reading comprehension has become an indispensable part of all English tests over the years. However, reading ability is still a relatively weak link for Chinese students. If we carefully examine the current English reading test, we can find that there are still some problems to be solved. Therefore, the teaching of college English reading combined with the cultivation of critical thinking ability can not only enable students to enlarge their vocabulary, better understand the main ideas of the text, and quickly locate information, but also enable students to guess the meaning of new words, thus making judgments and inferences and understanding the author's attitude and purpose. The cultivation and development of college students' critical thinking has not only become an important goal of higher education in today's world, but also is a higher requirement for higher education put forward by the rapid development of network society in the 21st century.

Critical thinking is sometimes referred to as "critical and creative thinking" and is an evaluation thinking involving both critical and creative thinking. In particular, it relates to the quality of reasoning and demonstration that supports a belief or course of action.[1] Since John Dewey, an 
American philosopher, first expounded, critical thinking has aroused heated discussion in various research fields such as philosophy, psychology and education. In the field of education, the significance of critical thinking has been widely recognized in western countries. From a historical point of view, the basic definition of critical thinking can be traced back to Socrates more than 2000 years ago. The literature on critical thinking originates from two main subjects: philosophy and psychology. Some philosophers tend to criticize the nature and quality of thinking. Psychologists, on the other hand, focus on the components of cognitive processes and operations for solving academic and practical problems. Critical thinking ability is what we want our students to develop their own ideas. Therefore, as teachers and educators, we have the responsibility to understand the key components of critical thinking ability in order to better apply it to our education and guidance. Critical thinking is a mode of thinking about any subject, content or problem, in which a thinker skillfully grasps his or her thoughts to improve the inherent structure of his or her thoughts and impose intellectual standards on them. Students need to master two dimensions of thinking to improve their thinking, they need to be able to identify "parts" of their thinking, and they need to be able to evaluate their use of these parts of thinking.

Since the 1980s, the teaching of critical thinking has been highly valued in western countries represented by the United States, and critical thinking has become one of the teaching objectives of current education. Critical thinking plays a very important role in cultivating students' creative spirit and innovative ability and is an important part of talent cultivation. Although scholars have expressed their views on critical thinking from different research angles and fields, everyone agrees that critical thinking is based on sufficient evidence and theoretical rational and reflective thinking, which can be used by people to make wise decisions and judgments. "Since critical thinking is part of the cognitive process, recognizing the existence of problems, forming strategies and psychological representations to solve problems is closely related to the development of critical thinking."[2] Critical thinking skills such as information collection, identification, judgment and evaluation, as well as critical thinking qualities such as curiosity, thirst for knowledge, self confidence, firmness, systematization, seeking truth, analysis, openness of thinking and inclusive mentality are undoubtedly one of the core competitiveness of contemporary college students in adapting to the times and the rapid development of society. "Critical thinking focuses on students' high-level thinking ability and sensitivity, instead of simply emphasizing students' passive acceptance of relevant English knowledge, it actively encourages students to carry out meaningful doubts so that they can actively ask some good questions, determine their assumptions according to certain criteria and find rationality.”[3]

One of the abilities that college students should possess in analysis and judgment is to actively classify the problems they find. What they will and understand, and what they cannot effectively solve after finding the problem, let teachers help solve the problem by classifying or defining and analyzing the problem. Once the problem is solved, the student can understand the problem he discovered more deeply. In this view, college English reading teaching should not be and cannot be pure language skills teaching. Critical thinking training is an important link that cannot be ignored in improving students' communication and understanding ability. In College English Curriculum Requirements, students should adopt effective reading strategies, which means that students should know how to use appropriate strategies to deal with reading materials effectively, which is also necessary for critical thinking. In order to meet this demand, college English teachers should apply critical thinking to college English reading teaching and teach students to participate in and actively read rather than passively accept. "Teaching a single teaching of knowledge or skills may make teaching lifeless; Teaching is not simply for teachers to impart facts and skills to students, but for students to think critically about topics, teaching materials, learning processes and the society in which they live."[4] This fully reflects the idea of turning English into an integral part of quality education from English only as a means of communication. As far as its teaching function is concerned, college English is a good carrier of "quality" education, shouldering the task of inheriting human culture and blending eastern and western cultures, and is one of the important hidden classes in emotional education. 


\section{Training Strategy of Critical Reading}

In recent years, although the central position of critical thinking in general education has been recognized by Chinese scholars, the significance of cultivating critical thinking ability has gradually been realized. Because there is no perfect research system, the research on critical thinking ability in China is far from enough. At present, the main focus of the research on critical thinking in China is on the effect and method of its cultivation, and there are relatively few tools to evaluate learners' critical thinking ability. Nowadays, critical thinking has been listed as an important goal in education, and the cultivation of critical thinking ability of many students is also outstanding. In recent decades, the application and development of critical thinking in the field of education has attracted special attention, with a large number of writing and academic papers on cultivating critical thinking ability. It is very important to cultivate students' critical thinking in teaching, especially the training of reading ability in English teaching should be a perfect combination of language and thought in order to realize real teaching.

In college English reading class, critical thinking training is necessary and effective. The traditional English reading teaching mode pays more attention to text structure analysis and neglects free writing. Pay attention to the appreciation of the text, ignoring the criticism of the text. On the basis of traditional teaching, teachers ignore learners' views and opinions and do not give them the opportunity to express themselves, so that students will not use critical thinking skills to learn languages. Reading is considered by many scholars as the most important skill for second language learners. "Although reading is a communication process, the success of communication is restricted by many factors. We should fully recognize the nature of reading and apply different methods to students of different levels in order to fully understand the text.”[5]

With the rapid development of communication technology, contemporary college students must have the comprehensive quality and ability to quickly collect information, identify the authenticity of information, judge the rationality of information and make objective and reasonable evaluation of information in a limited time. In recent years, the relationship between critical thinking and reading has attracted the attention of some researchers, and many attractive theoretical and practical studies have been carried out. More and more researchers are beginning to realize the psycholinguistic process behind seemingly simple reading comprehension. "The process of reading comprehension is not a simple passive process, but a process in which readers actively accept and absorb new information, and it is a process of critical and creative thinking. Therefore, critical and creative thinking in English reading is the key to reading comprehension. Whether readers can understand the text accurately and profoundly depends largely on whether his critical and creative thinking is brought into full play, in addition to the necessary language knowledge and background knowledge."[6] Reading is a process that includes identifying, interpreting and understanding written or printed materials. It is an understanding process that understands the meaning of written materials and uses some strategies to achieve good results. But define it from different angles, and different linguists have different views on defining reading. Early in 1917, Thorndike defined reading as “a positive process related to problem solving”. Recently, some scholars, such as Goodman, have expanded the definition of reading from a psychological point of view, focusing on its positive cognitive understanding. Pirozzi defined critical reading as "a very high level of understanding of written materials that need to be explained."[7] This should therefore be taken into account when designing reading comprehension exercises. For example, students can develop their reasoning ability through systematic practice, or ask questions to encourage students to predict the contents of titles and illustrations or texts from the end of previous paragraphs. According to this theory, the teacher should give some questions about this article, and then the students should take these questions to heart and try to find the answers to the questions in the reading process.

Designing critical and enlightening questions for discourse analysis and promoting college students' critical thinking ability through English learning under a reasonable evaluation mechanism; Creativity is the focus of quality education, and creativity is to improve students' critical thinking ability. Under a reasonable evaluation mechanism, it is the focus of quality education to promote students' critical thinking ability and innovation ability through English 
learning while the core of creativity is to improve students' critical thinking ability. Critical reading emphasizes the enthusiasm of the reading process. Readers are positive, not just receiving facts and information from the text, but summarizing their own views and opinions on what they read from the text. To sum up, critical reading investigates the author's specific skills, such as analyzing the use of language content and text structure. The steps of critical reading are as follows: The first step is to check what the text "says," which can be easily implemented by restatement of facts in the text. Then the second step is to focus on what the text "does" so as to argue, criticize and describe the structure and content of the text. The final step requires the reader to infer what the text "means" and then achieve the final overall interpretation of the meaning of the text. Before reading, the teacher intends to provide close to life and set up a natural and real situation. When reading, teachers should design colorful activities, such as matching work, group work, classroom work, role playing, short films and interviews, so that students can communicate with each other in the actual environment. Through various teaching activities, stimulate students' thinking, improve their interest in learning English and cultivate the spirit of cooperation. After reading, the group of students presented to the class. Reading occupies a prominent position in second language teaching and it has always been an important part of college English teaching. For example, before learning Unit 8 of Book 4 of New Horizon College English Third Edition Reading and Writing Course, A Meaningful Life, the teacher asked the students to discuss in groups: What can a person do to be more conducive to the realization of his meaning in life? When learning the text, ask questions: What is a meaningful life? In my life, even if there is no material return, what is worth pursuing? And what plans are there to implement it. After studying this article, ask students to discuss in groups: Is it important for a person to plan his future as early as possible? And what kind of career will you choose in the future? What is the most basic issue of meaningful life and so on. Through critical thinking training, students can actively find out the problems so that they can analyze and judge the difficulties they encounter and thus realize effective English language teaching. At the same time, teachers use critical teaching methods in teaching so that students can express the problems they encounter, and on this basis, they can practice the goal of English language teaching.

Before reading, the students will prepare their lessons. When reading, students express their views on a certain topic in class. After reading, the students and their teachers draw a conclusion, thus making the students change from passive learning to active learning. The first step is to design problems, provide materials, lead to thinking and then draw conclusions. In this teaching method, students master a large amount of background information before reading, and then conduct in-depth analysis and discussion will help develop their critical thinking. Teachers select rich reading materials, create a good classroom atmosphere, reasonably design classroom teaching, guide students to selectively accept external information, and provide opportunities for students to conduct critical reading and cultivate critical thinking ability. Students must seize the opportunity to exercise their critical thinking ability, broaden their knowledge and be diligent in thinking so as to further improve their cross-cultural communication ability. Taking Unit 2 of Book 1 of New Horizon College English Third Edition Reading and Writing Course, A child's clutter awaits an adult's return, as an example, the author conveys that the relationship between parents and children is the most difficult one to deal with and the most important one in life. In order to become mature, children need to undergo many changes before entering adulthood. Imagine how difficult it is for parents to change. Children are changing, learning and growing. Each generation is experiencing changes in life. We can clearly see the feelings of love between parents and children. On the basis of such a topic, critical questions are given for students to discuss: If you have a bad relationship with your parents, how can you improve your relationship with them? Good relations come from good communication, so how can we strengthen communication with our parents? Today, parents expect too much from their children and let students discuss the above topics and state their views. "Teachers should create a harmonious atmosphere in the classroom, encourage students to think and read, and strive to surpass works and authors to form different or opposite opinions from works and authors. During the debate, students are allowed to have differences in learning methods and abilities, to observe, interact and internalize the dispute process, and to encourage them to discuss 
freely. At the same time, teachers should ensure the time to discuss the topic and provide students with the opportunity to discover and think by themselves. Learn to discover information and make choices and judgments by using your own knowledge and skills, so that the reading class will become a place of democracy, harmony, expression of opinions, collision of ideas, vigor and vitality."[8]

\section{Conclusion}

In college English reading teaching, carrying out critical reading and cultivating students' critical thinking ability can further help students improve their ability to obtain information and think critically. Good at setting doubts and questioning in reading, reasonable classroom teaching design is the key to cultivating critical thinking ability. The proper evaluation of English reading teaching activities is the guarantee of cultivating critical thinking ability. With the development of society, the country's demand for innovative talents is increasing. Innovative talents must have creative thinking, and the improvement of creative thinking ability cannot be separated from the cultivation of critical thinking ability. Mobilizing the enthusiasm of the majority of students, enhancing their awareness and consciousness of cultivating their own critical thinking quality in college English reading, and promoting the formation of a macro teaching environment and teaching culture beneficial to the cultivation of students' critical thinking quality; To arouse college English teachers to attach great importance to the cultivation of critical thinking quality of college students and to provide them with relevant theoretical basis and research conclusions. In order to further enrich the research results of the critical thinking quality of Chinese college students, the critical thinking ability training should be carried out in college English reading teaching to broaden the research perspective of the critical thinking quality of college students.

\section{Acknowledgements}

Fund Project: This paper is the research result of "Design and Study on the Teaching of College English Reading Research on Teaching to Cultivate the Critical Thinking Ability" belonging to the Education and Research Project (Project No.JZ170098) of Young and Middle-Aged Teachers in Fujian Province (the Special Research Project of College English Teaching Reform) launched by the Department of Education in Fujian.

\section{References}

[1] Fisher, A. Critical Thinking: An Introduction [M]. Cambridge: Cambridge University Press, 2001.13.

[2] Qingxu Luo. On the Cultivation of Critical Thinking of College Students [J]. Higher Education Exploration, 2000(4)82.

[3] Ronghua Li. Research on Training of College English Critical Reading and Thinking Ability [J]. Journal of Yangtze University (Social Sciences Edition), 2012(1)105.

[4] Shuyuan Hong. A Study of Theory and Practice in Critical Thinking Oriented Teaching [J]. Journal of Guangzhou University (Social Science Edition), 2003(1)85.

[5] Lijun Xiong. The Enlightenment of Reading Theory and Skills on College English Reading Teaching [J]. Journal of Xi'an International Studies University, 2006(1)49.

[6] Sufen Wu. English Reading Teaching and the Cultivation of Critical and Creative Thinking Ability [J]. Research in Teaching, 2003(3)237.

[7] Pirozzi, R. Critical Reading, Critical Thinking [M]. New York: Longman, 2003.325.

[8] Xiayun Wu. The Cultivation of Critical Thinking Ability in College English Reading Teaching [J]. Journal of Liaoning Administration College, 2011(8)131. 